\title{
Estimating the Cost of Social-Democratic Government by Regression-Discontinuity Analysis of Close Elections
}

\author{
Jude C. Hays (jchays@uiuc.edu) \\ Assistant Professor of Political Science, University of Illinois, Urbana-Champaign \\ Robert J. Franzese, Jr. (franzese@umich.edu) \\ Associate Professor of Political Science, University of Michigan, Ann Arbor
}

8 November 2007

\begin{abstract}
This paper employs a regression-discontinuity (RD) design to ascertain the effects of socialdemocratic government on fiscal policy (budget deficits) and monetary policy (as reflected in inflation) and on currency and bond prices (i.e., exchange rates and yields). The RD design exploits the essentially random application of a treatment - in this case, social-democratic parties gaining government - near a discontinuous break in the probability of receiving that treatment - in this case, a discontinuous rise in the probability of entering government occurs as the social-democratic party seat-share crosses the plurality threshold-to identify and estimate the causal effect of the treatment (social-democratic government). One advantage of the $\mathrm{RD}$ design for researching these questions is that $\mathrm{RD}$ does not require, as have previously employed strategies, strong assumptions about if, how, or when market actors form political expectations, or about the quality and dissemination of political information, or about functional forms or explanatory-variable selection. Instead, the strategy relies on balancing observed and unobserved characteristics of the cases near the discontinuity on either side. Our findings suggest no or small and insignificant partisan-government effects except for a small and very short-term (one month), but statistically significant, currency-depreciation resulting from assumption of governmental power of social-democratic parties following close elections. ${ }^{1}$
\end{abstract}

\section{Introduction and Motivation:}

How do financial markets react to election outcomes? What price, if any, do citizens pay in lower government-bond and/or currency prices (i.e., higher yield or interest rates and/or exchange depreciation) for electing social-democratic governments? Does the price depend on a country's political and economic institutions, and how has the globalization of financial markets affected the price of social democracy? ${ }^{2}$ We follow Alesina et al. (1997), Herron (2000), Bernhard and Leblang (2006) in using the uncertainty surrounding elections as an opportunity to uncover market reactions

\footnotetext{
${ }^{1}$ Pending analyses will explore macroeconomic-policy differences near the discontinuity, and will explore the possibility of variation in the estimated effects corresponding to differences in political-economic institutions and/or in time-periods of higher or lower capital mobility. These analyses will help distinguish whether we observe Downsian convergence in policies and so financial-market outcomes; convergence in policies and outcomes from globalization-induced policycompetition; convergence in outcomes but not policy indicating lack of market concern about those policies; and/or political-economic institutional-contextual conditioning of partisan-government effects on policy and/or outcomes.

${ }^{2}$ We mean by social-democratic parties generically the main left-party in each parliamentary democracy, by socialdemocratic governments, governments (cabinet) including them, and, by social democracy, their common political program, which despite many changes remains committed to redistribution of wealth and risk (e.g., Garrett 1998).
} 
to partisan governments in democracies. Elections affect financial markets if they provide new and relevant information, which is to say if traders have ex ante uncertainty over and care about who will win. Closer elections generate more such uncertainty, and the literature contains many anecdotal references to some of them (Alesina et al.1997, Bachman 1992, Herron 2000). Systematic empirical study of the many close elections in OECD democracies, however, despite their great potential information about linkages between partisan democratic politics and markets, especially financial markets. ${ }^{3}$ Moreover, previous methods of assessing the impact of elections and/or of the partisanship of governments produced by them on macroeconomic policies and financial and other marketoutcomes have certain shortcomings that a regression-discontinuity (RD) design may alleviate. ${ }^{4}$ Some previous approaches rest on implausibly restrictive assumptions about how traders form political expectations (e.g., Alesina et al. 1997); others posit heroic assumptions about the quality and dissemination of political information (Herron 2000). The third, and by-far most-common, approach relies on standard linear-regression techniques or variegated generalizations thereof and so imposes debatable specification restrictions regarding functional forms, explanatory- and controlvariable selection, and the like (e.g., Garrett 1998, Franzese 2002, Clark 2003, Mosley 2003, Bernhard \& Leblang 2006, to list just a few in this style). ${ }^{5}$

In general, the problems all these approaches must confront are the usual ones. First, reverse causality: exchange-rate appreciation/depreciation and/or the costs of defending currency or bond prices affect right- and left-party core constituencies differently and therefore affect the probability of observing left or right governments. For example, an exogenous currency appreciation leads to

\footnotetext{
${ }^{3}$ For an exceptional more-than-anecdotal reference to the closeness of elections and so unexpectedness of electionoutcomes in the context of explaining economic policies and outcomes, see Carlsen \& Pedersen (1999). We count 78 close elections between 1957 and 2006 among OECD countries where close is defined as a left-right plurality seat differential between $\pm 10 \%$ of the two-party seat total. In this range a $5 \%$ swing in seats would reverse the winner.

${ }^{4}$ We thank John DiNardo, who initially suggested to and convinced one of us to study close elections on methodological grounds. Of course, he is not responsible for any errors.

${ }^{5}$ We do not discuss explicitly qualitative methods of analysis, which are also very common in these applications, but they would confront the same set of challenges, requiring adoption of some set of strategies like those described here, including qualitative analogues to the RD design and involving like sets of tradeoffs, to gain empirical leverage.
} 
lower exports and higher unemployment, which, in turn, increases the appeal of leftist platforms and the probability of a left party election victory or, alternatively, depreciation lowers the purchasing power of the poor especially, making redistribution more socially desirable. Relatedly, strategies of identification that rest on specifying markets' expectations-formation or that assume environments of perfect political or economic information (or specific degrees of absolute or relative imperfection) will fail to the extent that those specifications or assumed environments differ from actual empirical ones. Second, omitted-variable bias: many potentially observable variables may cause both currency and bond-market performance on one hand and the electoral success of parties on the other, and any analysis will have omitted some of these. For example, oil-price shocks affect both interest rates and the effectiveness of the economic policies in a particular party's policy toolkit and so its probability of winning elections. Not all analyses have controlled such possibilities, and, again, even those that have controlled most candidates will have specified functional forms by which those variables enter, which will introduce biases insofar as those specifications differ from the empirically accurate ones. Likewise, omitted unobservable variables can induce bias; for example, societies "in decline" or whose citizens perceive as "in decline" may be more likely to exhibit poor economic-performance and so be more or less likely to elect conservative parties to office. Third, in contexts with forwardlooking political-economic actors, of which financial markets are perhaps the archetype, naive prepost comparisons might fail to find partisan-government effects, even large ones, if they are longanticipated by traders. Once more, insofar as the pre-post windows failed to correspond to typical anticipatory leads, either in delineating pre-post periods or in setting window-width, or insofar as leads vary in some unaccounted manner, bias toward null findings would arise. For all of these sorts of reasons, we might find a strategy that relied less on such strong identification and specification assumptions, i.e., relatively more non-parametric strategies, more capable of convincing skeptical audiences, especially if it uncovers an effect of government partisanship. ${ }^{6}$

\footnotetext{
${ }^{6}$ The cost of less restrictively specified approaches, of course, is their relative inefficiency. To have the random falling
} 
The RD design is one such relatively non-parametric approach. RD analysis (DiNardo and Lee 2004, Lee 2001, Lee et al. 2004) approaches a particular outcome or choice—e.g., social-democratic entry to government — as an experimental treatment and the election as the mechanism determining the probability of treatment. Thus, one can interpret the RD design as a kind of selection model with seat-share as the latent variable influencing whether treatment is received (Heckman 1978, 1979; Johnston and DiNardo 1997:446-449). This treatment effect is identified provided a threshold exists at which a discontinuous break occurs in the probability treatment (Hahn et al. 2001). In our context, $\mathrm{RD}$ analysis may find success exploiting one quasi-experimental aspect of democratic governmentformation. Namely, a discontinuity arises at the threshold of plurality status, where a sharp break (increase) in the probability of that party gaining government power (or a share of it ${ }^{7}$ ) occurs as the seat-share crosses plurality, making the party in question the largest party. In parliamentary systems with plurality-majority electoral systems, which tend to be systems of two-party competition for single-party majority control of government, the reason for the break at the plurality vote-share is self-evident and the magnitude of the break is near total, from $0 \%$ probability of controlling any of government to $100 \%$ probability of controlling $100 \%$ of government. In fact, regardless of electoralor party-systemic features, a discontinuous break occurs in the probability of gaining some share of government at the plurality threshold (although not always from $0 \%$ expected-control to $100 \%$ : see note 7 for implications) in all parliamentary systems. Inter alia, the discontinuity occurs because the largest party typically receives nomination as the formateur, granting it first opportunity to propose a

on one side or other of a knife-edge discontinuity (see ensuing text) produce a statistically appreciable difference asks a great deal of data. In more parametric approaches, contrarily, one assumes or derives from theory (which is the same thing from an empirical-estimation standpoint) relations of specified forms between specified variables. In these moreparametric approaches, this pre-specification of the empirical model with specific form and contents is what provides identification and essentially substitutes theory/assumption/priors for (usable variation in) data.

${ }^{7}$ A complication arises from this possibility that plurality parties in some systems may enter coalition and/or minority governments, which, in all likelihood, implies different degrees of control over policy, and so different magnitudes of treatment than would entry to single-party majority government. We do not yet address this complication, or a similar one arising from some social-democratic parties representing greater or lesser programmatic and ideological, and so likely policy, alternatives from other parties across systems. Again, this suggests varying magnitude of treatment in the $\mathrm{RD}$ design. Estimated effects that ignore these complications are inefficient estimates of average-treatment averageeffects. Gauging these variations in treatment magnitude within the analysis would sacrifice some of RD's relative nonparametric and lack-of-pre-specification advantages for gains in efficiency: a common tradeoff in empirical analysis. 
government and because the bargaining power of the largest party tends more generally to be discontinuously greater than that of the second-largest. ${ }^{8}$

The important insight on which RD empirical designs rest is that, given ex ante uncertainty over the outcomes (governments), near the discontinuity (here, in close elections), the treatment (socialdemocratic government) is essentially assigned randomly. Metaphorically, voter support has some randomness to it and, therefore, whether an election competed at or near the knife-edge of plurality lands slightly to one side or the other of the center of that honed blade of a plurality tie, and so the government-formation process falls to one side or the other (social-democratic-party seat-plurality and so discontinuously higher probability of social-democratic government, or close-second and so discontinuously lower) grows increasingly random as we define near increasingly narrowly. This randomness of close elections' government outcomes establishes their quasi-experimental status. Moreover, advantageously, one can explore the empirical validity of the assumption of random treatment-selection for a given definition of near to some extent because the power of RD, as in any randomized-trial design (including true experimentation or matching), arises from "balancing" relevant observable and unobservable variables in the treatment (social-democratic government) and control (other government) groups. Thus, the quality of the balancing on either side and near the discontinuity is directly empirically measureable, at least with regard to the observables deemed relevant and exogenously predetermined ${ }^{9}$ (Mebane and Sekhon XXXX).

Furthermore, the RD design may be especially appropriate for studying financial-market reaction to social-democratic governments because valid pre-post election comparisons by RD do not require strong assumptions about how traders process information and form expectations, and RD does not require restrictive pre-specification of functional form and controls. With the balance achieved in

\footnotetext{
${ }^{8}$ For theoretical models establishing such breaks in the probability of entering government, see: XXXX; for empirical confirmation, see: XXXX.

${ }^{9}$ In this stage, as in propensity-score matching, the analysis must first determine which observables are relevant and exogenously predetermined, and so must be balanced, and which are endogenous to the outcome and so should/need not.
} 
observables demonstrable, positive findings (of significant partisan-government effects) may prove less assailable. Moreover, in this case, even a null result (failure to find significant partisan effects) would provide considerable evidence against rational partisan theory because that theory identifies close elections as creating greatest uncertainty for financial markets (Alesina et al. 1997, Bachman 1992). We will also use the RD design to explore differences in macroeconomic policy, particularly in inflation and budget deficits representing monetary and fiscal policy, on both sides of the plurality threshold. As elaborated below, failure to find significant macroeconomic policy differences could lend support to Rodrik's “golden straightjacket” hypothesis (2000) or alternatively to Clark's moregeneral Downsian-convergence hypothesis (2003). In turn, we can distinguish those alternatives by exploring whether differences at the discontinuity have faded with rising capital mobility or were instead present more continuously across all democratic contexts. Conversely, differences in policy but not in the "price" of social democracy would support the conclusion that financial markets are not averse to left governments per se, either because their policies are as or more efficient than right governments' in some contexts (Garrett 1998) or are sufficiently close as to retain capital (Boix 1998). Alternatively, such results could arise because capital is not especially attentive to these particular policies, which might support Mosely (2000). ${ }^{10}$ In addition, we will conduct these RD analyses in subsamples grouped (a) by political-economic institutions and (b) by time period to explore whether and how degrees of partisan policy-differences, prices for social democracy, and, in combination, policy-maneuvering room (a) may vary across political-economic institutional contexts and (b) may have changed over these periods of rising trade and capital-market integration. The latter, as noted, will be particularly useful in distinguishing the Downsian from the globalization induced partisan-convergence arguments (see also note 1).

\section{Discussion}

\footnotetext{
${ }^{10}$ Except that these policies are among those, perhaps foremost among those, to which Mosely (2000) argues and finds financial-market actors are particularly attentive.
} 
Elections, like any events, can only affect financial markets if they provide new information, which is to say uncertainty about the outcome must exist ex ante. Uncertainty is only a necessary condition, though. Traders must also care who wins the election. Scholars disagree over whether we can generalize about the revealed political preferences of financial markets, particularly partisan preferences, by the way these markets respond to electoral information. Some scholars, particularly proponents of rational partisan theory, argue that financial markets react strongly to new information about the partisanship of future governments imposing a high price on citizens who choose social democratic representatives (Alesina et al. 1997, Herron 2000). Others, most notably those from the varieties of capitalism literature, contend that traders only worry about macroeconomic performance and not policy or partisanship per se (Mosley 2000, Garrett 1998). Since, according to this camp, no uniform systematic relationship between partisanship and inflation exists—e.g., in countries with corporatist labor-market-institutions, left governments may associate with stronger macroeconomic performance - the cost of social democracy may be quite low or even negative (i.e., benefits). Still others (e.g., globalization scholars) maintain that the internationalization of financial markets has placed a "Golden Straightjacket" on governments, shrinking the policy space between the right and left (Rodrik 2000). Clark (2003) argues and shows much evidence suggesting that, rather than a new, globalization-induced straightjacket on partisan governments' macroeconomic policies, the basic fact of democratic competition induces and has always induced Hotelling-Downsian convergence in the macroeconomic policies of left and right governments.

All scholars would agree, however, that close elections generate the most uncertainty. Consider the most recent general election in Germany, for example, which is highly suggestive of the effect that close elections can have on financial markets. The two major parties competing this electionthe Social Democrats and Christian Democrats—-tied with approximately $38.5 \%$ of the vote; in the end, government-formation emerged to the Social Democrats' favor due to the relative success of its 
junior coalition partner, the Greens. Seemingly in response to this, the German stock market dropped five percentage points to its lowest level in five years. ${ }^{11}$ The literature also contains many anecdotal references to close elections. For instance, Alesina et al (1997) write about the impact of Truman's and Clinton's close victories in 1948 and 1992 on interest rates. Similarly, Bachman (1992) argues that US presidential elections in 1976 and 1980 affected the forward exchange rate bias because they were close whereas the 1984 election had no impact on currency markets because the outcome was widely anticipated. Herron (2000) studies one of the closest elections in recent British history and finds that had Labour been elected, the LIBOR rate would have risen by about 1 percent and the FTSE-100 index would have dropped by 9.5 percentage points.

These anecdotes are interesting and important, but are they representative or exceptional? Are their understandings as examples of market reactions to political uncertainty accurate? We cannot know these kinds of answers without systematic empirical study of close elections. Between 1957 and 2006, we count 78 close elections (defined as a left-right seat-differential of $\pm 10 \%$, so that a $5 \%$ swing would have switched the winner) in 20 OECD countries. ${ }^{12}$ Despite the wealth of information that these elections may provide about the linkages between partisan politics and financial markets, no one to our knowledge has studied them systematically. This represents a large gap in political economy of finance research because these elections may hold the key to resolving the controversy over the "price" of social democracy and globalization/convergence.

The debate in social science about whether markets constrain democratic choice is long-standing, perhaps fundamental. The locus classicus on this topic is Lindblom's (1977) Politics and Markets, which emphasized the "privileged position of capital," i.e., capital's ability to withhold investment as a credible threat against governments thinking to act against their interests, at least relative to labor's

\footnotetext{
${ }^{11}$ Mark Lander, “German Outcome Casts Renewed Chill Over Economy." New York Times, September 24, 2002. The election was held on Sunday, September 22, 2002.

${ }^{12}$ The usual 21, less the non-parliamentary U.S.
} 
credibility in, conceivably, withholding work or political support. ${ }^{13}$ Since Lindblom wrote, much has changed in this important debate. Numerous theoretical developments in economics and political science have advanced and/or modified our understanding of these political-economic strategic interactions considerably, but the central logic revolving around these competing threats of capital and labor against their governmental agents has essentially remained. Contemporary approaches emphasize strategic interaction, credibility, and agency, and we have gained great richness in these and many further understandings thereby. Also, and more centrally of interest to us here, much of the focus has shifted to the degree to which the globalization of financial markets may have strengthened capital's threat in this battle, and how far therefore it may be constraining governments autonomy by "disciplining" those who choose unorthodox policies.

In the spirit of Lindblom and this debate, we aim to ascertain if financial markets react to socialdemocratic government in ways that impose costs on the societies they govern. To this end, we draw from theoretical developments in both economics and political science to which we alluded above. We draw heavily from rational-expectations macroeconomics (Fama 1970, Lucas 1987), particularly the idea that market participants anticipate policy changes and react to their expectations of events before they happen, in real time as new information arrives. The general notion that macroeconomic policymaking is fundamentally political, and potentially partisan, we draw from the literatures on electoral (Tufte 1978, Nordhaus 1975) and partisan policy and business cycles (Hibbs 1987, Alesina 1989). We recognize the possibility that political-economic institutions may mediate partisan effects, an idea that receives perhaps greatest current emphasis in the varieties of capitalism literature and its predecessors (Garrett 1998, Kitschelt et al. 1999, Hall and Soskice 2001). Finally, we inform our empirical methodology and strategies by theories of government formation that link electoral and coalition outcomes (Laver and Shepsle 1996, Tsebelis 1999).

\footnotetext{
${ }^{13}$ On the political front, strategically, the lack of credibility derives from labor's generally having only worse options than continuing to support left parties who concede considerable ground against capital's threat.
} 
3. Methods/Techniques. The methods used to assess the impact of elections on financial markets have been problematic for a number of reasons. The existing studies rest on unreasonable assumptions about the way that traders form political expectations (Alesina et al. 1997), posit heroic assumptions about the quality and dissemination of political information (Herron 2000), or make questionable specification decisions related to functional forms and (or) variable selection (Garrett 1998, Mosley 2000). As a result, the research fails to yield sound inferences about the price of social democracy in a world of global financial markets.

It is possible to avoid these problems with regression discontinuity (RD) analysis (DiNardo and Lee 2001, Lee 2001, Lee, Moretti, and Butler 2002). In terms of research design, one can think of a particular social choice-e.g., when a district's constituents choose a Democratic congressperson or a firm's workers choose to form a union — as the treatment in an experiment and the election as the mechanism that determines the probability that the treatment is administered. In general, the RD design can be easily interpreted in terms of the standard selection model with vote share as the latent variable influencing whether or not the treatment is received (Heckman 1978; Johnston and DiNardo 1997, 446-449). The treatment effect is identified as long as there is a threshold at which there is a discontinuous break in the probability of observing the treatment (Hahn et al. 2001). Thus, RD analysis can be used to exploit the quasi-experiment generated by routine government formation processes in parliamentary democracies. Because the largest party is typically given the first opportunity to form a government, plurality status marks an important threshold at which there is a discontinuous break in the probability of observing a particular party in power.

Moreover, unless the outcomes of close elections are knowable with certainty in advance, near the discontinuity the "treatment" can be analyzed essentially as if it is assigned randomly. Another attractive feature of this framework is that the assumption of random selection can be tested. As in a randomized trial, the power of randomization comes from the fact that it "balances" the relevant 
observable and unobservable variables in the treatment and control groups. A simple test of this framework, therefore, is a test of whether any observable variable is balanced near the discontinuity. In other words, if the RD design is valid, there should be no significant discontinuity near the threshold for any relevant pre-treatment or exogenous variable. The existence of a significant discontinuity at the threshold for relevant exogenous or pre-treatment variables allows the researcher to reject the design. Likewise, in the absence of discontinuities in these variables, the design provides a consistent estimate of the treatment's effect in the presence of omitted variables, something the more traditional regression designs of Garrett, Mosley, and others do not do.

The RD design is particularly appropriate for studying financial markets. One potential difficulty in the analysis of financial data is that such markets are forward looking. Thus, even in the presence of a large treatment effect, naive pre-post comparisons might fail to find such an effect if they have been long anticipated by traders. Forward-looking behavior will be less relevant when election outcomes are uncertain. Consequently, with the $\mathrm{RD}$ design, it is possible to make valid pre-post election comparisons without making strong assumptions about the way traders process information and form expectations. It is also important to note that a null result would provide unusually powerful evidence against the rational partisan hypothesis since this theory identifies close elections as creating the most uncertainty for financial markets (Alesina et al. 1997, Bachman 1992). In order to interpret a null result, we will also use the RD design to look for differences in policy regimes on both sides of the plurality threshold, particularly differences in inflation and budget deficits. If we find that there are no differences, this would support the "straightjacket" hypothesis (Rodrik 2000). On the other hand, if we find that there are differences in policy, this would support the conclusion that financial markets are not averse to left-wing governments per se (Garrett 1998, Mosely 2000).

Building on the work on government formation, we will gauge how markets react to cases in which SDP's forge government coalitions of various kinds. If financial markets punish SDGs, one 
would expect to see traders selling a country's currency and government bonds soon after a close election in which the Social Democrats just barely win a plurality of seat shares in the legislature. Operationally, one would expect to see speculative pressure (Eichengreen, Rose, and Wyplosz 1995) on the currency and a drop in bond prices (or, equivalently, an increase in bond yields). One would expect the opposite after close elections in which the Social Democrats just barely lose a plurality. In addition, we will examine these relationships in the early (1960-1980) and late (1980-2000) subperiods and across subsamples of countries with distinct political-economic institutions. we will also test to see if rates of inflation and budget deficits are systematically higher after close elections in which the Social Democrats just barely win a plurality of seat shares in the legislature when compared with inflation and deficits after close elections in which they just barely lose.

4. Design. we present a more formal exposition of the RD design below based on DiNardo and Lee (2001) and Hahn et al. (2001). we focus on discontinuities in bond prices, but the basic logic outlined is general and applies to currency prices and policy variables as well. Let $\Delta P_{i, t}$ be the time t change in the price of a government bond in country $i$ and $\Delta X_{i, t-1}$ be the time t-1 change in a vector of its observable determinants. Assume that an election is held at time t-1, and define $\Delta S D_{i, t-1}^{e}$ as the change in the market's expectation that a social democratic administration will be in place at time $t$ $\left(S D_{i, t}=1\right)$ based on the election results. Finally, let $\varepsilon_{i, t}$ be an independent time t price shock. Together these variables give the following model for the bond's post-election price dynamics:

$$
\Delta P_{i, t}=\Delta X_{i, t-1} \gamma+\Delta S D_{i, t-1}^{e} \beta+\varepsilon_{i, t}
$$

The market's political expectations depend crucially on whether the Social Democrats win a plurality of legislative seats. Define $V_{i, t-1}$ as the size of the Social Democratic plurality, measured as a percentage of total legislative seats. Note that when $V_{i, t-1}=0$, the Social Democrats tie for the largest parliamentary delegation, and a negative plurality $\left(V_{i, t-1}<0\right)$ measures the size of the seat gap 
between the Social Democrats and the election winner. The market's political expectation at time $\mathrm{t}-$ $1\left(S D_{i, t-1}^{e}\right)$ is defined by the following equation:

$$
S D_{i, t-1}^{e}=E\left[S D_{i, t} \mid V_{i, t-1}=V\right]=\operatorname{Pr}\left[S D_{i, t}=1 \mid V_{i, t-1}=V\right] .
$$

In turn, $V_{i, t-1}$ is influenced by $X_{i, t-1}$ :

$$
V_{i, t-1}=v\left(X_{i, t-1}\right)+U_{i, t-1}
$$

From equations (2) and (3), it follows that $\Delta S D_{i, t-1}^{e}$ will not be independent of variables omitted from $\Delta X_{i, t-1}$ and this, in turn, makes it difficult to get an unbiased test the null hypothesis of market indifference $\left(H_{0}: \beta=0\right)$.

In previous work this hypothesis has been tested directly by carefully specifying the variables and (or) functional forms for $\Delta X_{i, t-1}, \Delta S D_{i, t-1}^{e}$, and $\varepsilon_{i, t}$. However, given the large number of choices that have to be made, these results are controversial. Moreover, if some of the $X^{\prime} s$ are unobservable, the omitted variable problem becomes even more complicated. The RD design provides more conclusive results because none of these assumptions are necessary to test the null hypothesis of market indifference. One does not have to correctly specify the variables in $\Delta X_{i, t-1}$ or posit a model for how the market forms its political expectations. To see this, let $e$ be an arbitrarily small number. As long as (1) $E\left[\Delta X_{i, t-1} \mid V_{i, t-1}=V\right]$ is continuous in $V$ at $V=0$ and (2) $E\left[S D_{i, t} \mid V=+e\right] \neq E\left[S D_{i, t} \mid V=-e\right]$, the null hypothesis can be tested indirectly by testing the continuity of $\Delta P_{i, t}$ at $V_{i, t}=0$. Two things make the design even more attractive: the first assumption is testable, and the second is all but guaranteed by the rules of government formation in parliamentary democracies. The basic idea behind this test is illustrated in Figure 1. 


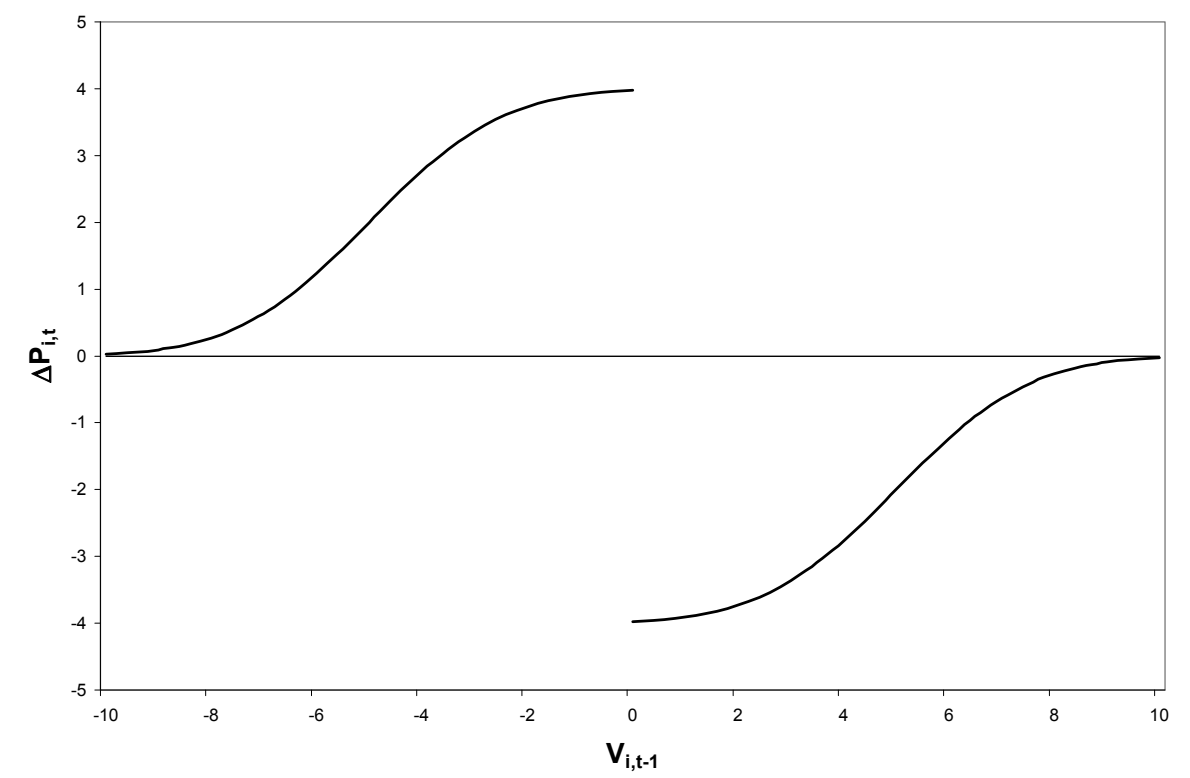

Figure 1. Testing for Discontinuities in $\Delta \mathbf{P}_{\mathrm{i}, \mathrm{t}}$ at $\mathrm{V}_{\mathrm{i}, \mathrm{t}-1}=\mathbf{0}$

A break like the one pictured above would imply that financial markets "price" government partisanship.

The financial and policy data for this project is readily available from IMF and OECD sources. This data needs to be collected and standardized for valid cross-national comparisons. The electoral data, which includes election dates and party seat allocations, is available from Keesing's Record of World Events. The sizes of Social Democratic pluralities also need to be computed. A sample of data for close parliamentary elections in several majoritarian democracies during the period 1960-2000 is presented below in Table 1. (Note that the table includes bond yields, which are negatively related to bond prices.) Interestingly, the only times bond yields (prices) decreased (increased) were after close elections producing right-wing governments. Furthermore, the four largest increases in bond yields occurred after close elections producing left-wing governments. These elections, by themselves, are far from conclusive empirical evidence, but they do show the potential fruitfulness of constructing a "close elections" dataset. 


\begin{tabular}{|c|c|c|c|c|c|c|}
\hline \multicolumn{7}{|c|}{ Close Elections Producing Right Governments, 1960-2000 } \\
\hline Country & $\begin{array}{c}\text { Election Date } \\
(\mathrm{t}-1)\end{array}$ & Left Seats & Right Seats & \begin{tabular}{|c|}
$\%$ Of Two Party \\
Seats $\left(\mathrm{V}_{\mathrm{i}, t-1}\right)$ \\
\end{tabular} & $\begin{array}{l}\text { Standardized Change in } \\
\text { Markets from } \mathrm{t}-1 \text { to } \mathrm{t} \text { : }\end{array}$ & Bond Yields \\
\hline Australia & September 12, 1961 & 62 (Labour) & 62 (Liberals) & $50 \%(0)$ & September to October & -0.51 \\
\hline Australia & October 25, 1969 & 59 (Labour) & 66 (Liberals) & $47 \%(-3)$ & October to November & 0.05 \\
\hline Australia & February 23, 1970 & 59 (Labour) & 66 (Liberals) & $47 \%(-3)$ & February to March & 0.22 \\
\hline New Zealand & November 28, 1981 & 43 (Labour) & 47 (National) & $48 \%(-2)$ & November to December & -0.79 \\
\hline New Zealand & November 6, 1993 & 45 (Labour) & 50 (National) & $47 \%(-3)$ & November to December & 0.14 \\
\hline & & & & & AVERAGE CHANGE & -0.18 \\
\hline \multicolumn{7}{|c|}{ Close Elections Producing Left Governments, 1960-2000 } \\
\hline Country & $\begin{array}{c}\text { Election Date } \\
(\mathrm{t}-1)\end{array}$ & Left Seats & Right Seats & \begin{tabular}{|c|}
$\%$ Of Two Party \\
Seats $\left(V_{i,-1}\right)$ \\
\end{tabular} & $\begin{array}{l}\text { Standardized Change in } \\
\text { Markets from t-1 to t: }\end{array}$ & Bond Yields \\
\hline Australia & May 18, 1974 & 66 (Labour) & 61 (Liberals) & $52 \%(+2)$ & May to June & 2.72 \\
\hline Australia & March 24, 1990 & 78 (Labour) & 69 (Liberals) & $53 \%(+3)$ & March to April & 0.86 \\
\hline Canada & October 30, 1972 & 109 (Liberals) & 107 (Conservatives) & $50 \%(0)$ & November to December* & 0.11 \\
\hline United Kingdom & October 15, 1964 & 317 (Labour) & 304 (Conservatives) & $51 \%(+1)$ & October to November & 0.52 \\
\hline United Kingdom & February 28, 1974 & 301 (Labour) & 296 (Conservatives) & $50 \%(0)$ & February to March & 0.55 \\
\hline & & & & & AVERAGE CHANGE & 0.95 \\
\hline
\end{tabular}

*After several recounts, the final election results were announced November 11, 1972.

\section{Table 1. Sample Data for Close Parliamentary Elections}

5. Limitations/Pitfalls. There are a couple of important limitations and potential pitfalls to the approach we am proposing. One obvious problem stems from the fact we am relying on an ex post measure of ex ante uncertainty. Unfortunately, this is the best that can be done. In order to construct a true ex ante measure of electoral uncertainty, we would need to use pre-election polls and these surveys are not available on the scale we require. However, we am confident that the ex post measure is unbiased. Some elections that are forecasted to be close are landslides and some landslides are predicted to be close, but these occurrences are rare and random.

Another limitation stems from the small number of close elections. Forty-six elections at the plurality threshold may be too few to identify with confidence systematic differences on either side. However, because market reactions are theorized to be the largest at the threshold, forty-six elections should be adequate. Even if this number is too small, there is still reason to begin collecting a "close elections" dataset. The number of close elections will only grow over time as the German general election this fall demonstrates. If the database is expanded, it will eventually contain a sufficient number of close elections to draw strong conclusions.

In order to get forty-six close elections, we have to pool countries with widely disparate 
institutions and draw cases from an extended historical period. While this kind of pooling is common practice in comparative political economy (e.g., Beck and Katz 1995), it is potentially problematic. For example, including both parliamentary democracies with majoritarian electoral systems and parliamentary democracies with proportional representation electoral systems in the sample may be inappropriate because the former systems produce single-party left governments while the latter produce left-led coalition governments. It is possible that financial markets view these two types of governments very differently: a left-led government is presumably more constrained than a singleparty left government. If the analysis is sensitive to important institutional differences across countries, this will not be too much of a problem. In fact, a null result could be turned into an institutionally rich finding such as markets react strongly to left-wing governments in countries with majoritarian electoral institutions but not to the election of left-wing governments in countries with proportional representation electoral systems (Freeman, Hays, and Stix 2000). Again, the reason for pooling is the small number of observations, but this problem becomes less serious as the number of close elections grows. 


\section{REFERENCES}

Alesina, A. "Politics and Business Cycles in Industrial Democracies," Economic Policy, 1989, vol. 8, pp. 55-98.

Alesina, A., Roubini, N., with Cohen, G.D. 1997. Political Cycles and the Macroeconomy. Cambridge: MIT Press.

Bachman, D.D. 1992. "The Effect of Political Risk on the Forward Exchange Bias: The Case of Elections," Journal of International Money and Finance 11(2):208-19.

Beck, N and J. Katz. "What to Do (and Not to Do) with Time-Series-Cross-Section Data in Comparative Politics” American Political Science Review, 1995, vol. 89, pp. 634-647.

Bernhard, W. and D. Leblang. "Democratic Processes and Political Risk: Evidence from Foreign Exchange Markets," American Journal of Political Science, 2002, vol. 46, pp. 316-333.

Bernhard, W., Leblang, D. 2006. Democratic Processes and Financial Markets: Pricing Politics. Cambridge: Cambridge UP.

Blomberg, S. B. and G. D. Hess. "Politics and Exchange Rate Forecasts," Journal of International Economics, 1997, vol. 43, pp. 189-205.

Carlsen, F., Pedersen, P.F. 1999. "Rational Partisan Theory: Evidence for Seven OECD Economies," Economics and Politics 11(1):13-32.

Chang, M. "Reading the News: Elections, Institutions and Market Speculation in Mexico and Korea." Paper presented at the Annual Meeting of the American Political Science Association, Boston, 2002.

Chang, W. and C. Lai, "Election Outcomes and the Stockmarket: Further Results," European Journal of Political Economy, 1997, vol. 13, no. 1, pp. 143-155.

Clark, W.C. 2003. Capitalism, Not Globalism: Capital Mobility, Central Bank Independence, and the Political Control of the Economy. Ann Arbor: University of Michigan Press.

Corporale, T. C. and K. B. Grier (2000) Political Regime Change and the Real Interest Rate Journal of Money, Credit and Banking 32:320-334.

DiNardo, J., Lee, D.S. 2004. "Unionism in California and the United States: Using Representation Elections to Evaluate their Impact on Business Establishments,” in Milkman, R., Voss, K., eds., Rebuilding Labor:Organizing and Organizers in the New Union Movement, Ithaca: Cornell UP. 
Eichengreen, B., A. Rose and C. Wyplosz. "Exchange Market Mayhem: The Antecedents and Aftermath of Speculative Attacks”Economic Policy, 1995, vol. 21, pp. 249-312.

Fama, E. "Efficient Capital Markets: A Review of Theory and Empirical Work," Journal of Finance, 1970, vol. 25, no. 2, pp. 383-417.

Franzese, R. 2002. Macroeconomic Policies of Developed Democracies. Cambridge: Cambridge UP. Freeman, J.R., J.C. Hays and H. Stix. "Democracy and Markets: The Case of Exchange Rates," American Journal of Political Science, 2000, vol. 44, no. 3, pp. 449-468.

Garrett, G. 1998. Partisan Politics in the Global Economy. Cambridge: Cambridge UP.

Gemmill, G. "Political Risk and Market Efficiency: Tests Based in British Stock and Option Markets in the 1987 Election," Journal of Banking and Finance, 1992, vol. 16, pp. 211-231.

Haggard, S., 2000, The Political Economy of the Asian Financial Crisis (Washington, D.C.: Institute for International Economics).

Hahn, J., Todd, P. van der Klaauw, W. 2001. "Identification and Estimation of Treatment Effects with a Regression-Discontinuity Design,” Econometrica 69(1):201-209.

Hays, J., J. Freeman, and H. Nesseth. "Exchange Rate Volatility and Democratization in Emerging Market Countries," Paper presented at the Annual Meeting of the American Political Science Association, San Francisco, 2001.

Heckman, J.J. "Dummy Endogenous Variables in a Simultaneous Equations System," Econometrica, 1978, vol. 46, pp. 931-59.

Heckman, J. 1978. "Simple Statistical Models for Discrete Panel Data Developed and Applied to Test the Hypothesis of True State Dependence against the Hypothesis of Spurious State Dependence," Annals de INSEE(September, Special Issue):227-69.

Heckman, J. 1979. “Sample Selection Bias as a Specification Error,” Econometrica 47(1):153-61.

Herron, M.C. 2000. "Estimating the Economic Impact of Political Party Competition in the 1992 British Election," American Journal of Political Science 44(2):326-37.

Herron, M. C., J. Lavin, D. Cram, and J.Silver. "Measurement of Political Effects in the Stock Market," Economics and Politics, 1999, vol. 11, pp. 51-82.

Hibbs, D., 1987, The Political Economy of Industrial Democracies (Cambridge, MA: Harvard 


\section{University Press).}

Johnston, J., DiNardo, J. 1997. Econometric Methods. New York: McGraw-Hill.

Kitschelt, H., P. Lange, G. Marks and J.D. Stephens, 1999, Continuity and Change in Contemporary Capitalism (New York: Cambridge University Press).

Laver, M. and K.A. Shepsle, 1996, Making and Breaking Governments: Cabinets and Legislatures in Parliamentary Democracies (Cambridge: Cambridge University Press).

Lee, D.S., "The Electoral Advantage to Incumbency and Voters' Valuation of Politicians' Experience: A Regression Discontinuity Analysis of Close Elections," 2001, NBER Working Paper No. 8441.

Lee, D.S., Moretti, E., Butler, M.J. 2004. "Do Voters Affect or Elect Policies? Evidence from the U.S. House," Quarterly Journal of Economics 119(3):807-60.

Lin, T. and B. Roberts. "Markets and Politics: The 2000 Taiwanese Election." Paper presented at the Annual Meeting of the Midwest Political Science Association, Chicago, Illinois, 2001.

Lindblom, C., 1977, Politics and Markets (New York: Basic Books).

Lobo, B. and D. Tufte. "Exchange Rate Volatility: Does Politics Matter?" Journal of Macroeconomics, 1998, vol. 20, pp. 351-365.

Lucas, R., 1987, Models of Business Cycles (New York: B. Blackwell).

MacIntyre, A. "Institutions and Investors: The Politics of the Economic Crisis in Southeast Asia," International Organization, 2001, vol. 55, pp. 81-122.

Mosley, L. "International Financial Markets and National Welfare States" International Organization, 2000, vol. 54, no. 4, pp. 737-774.

Mosley, L. 2003. Global Capital and National Governments. Cambridge: Cambridge UP.

Nordhaus, W. "The Political Business Cycle," Review of Economic Studies, 1975, vol. 42, pp. 169190.

Pantzalis, C., D. A. Strangeland, and H. J. Tuttle. "Political Elections and the Resolution of Uncertainty: The International Evidence," Journal of Banking and Finance, 2000, vol. 24, pp. 1575-1604.

Roberts, B. E. "Political Institutions, Policy Expectations, and the 1980 Election: A Financial Market 
Perspective," American Journal of Political Science, 1990, vol. 34, pp. 289-310.

Rodrik, D. "How Far Will International Economic Integration Go?" Journal of Economic Perspectives, 2000, vol. 14, pp. 177-86.

Tufte, E.R., 1978, Political Control of the Economy (Princeton, N.J.: Princeton University Press).

Tsebelis, G. "Veto Players and Law Production in Parliamentary Democracies: An Empirical Analysis," American Journal of Political Science, 1999, vol. 93, no. 3, pp. 591-608.

Van der Ploeg, F. "Election Outcomes and the Stockmarket," European Journal of Political Economy, 1989, vol. 5, pp. 21-30. 
Figure 1. Short-Run Currency Market Reaction to Left-Right Parliamentary Seat Differential
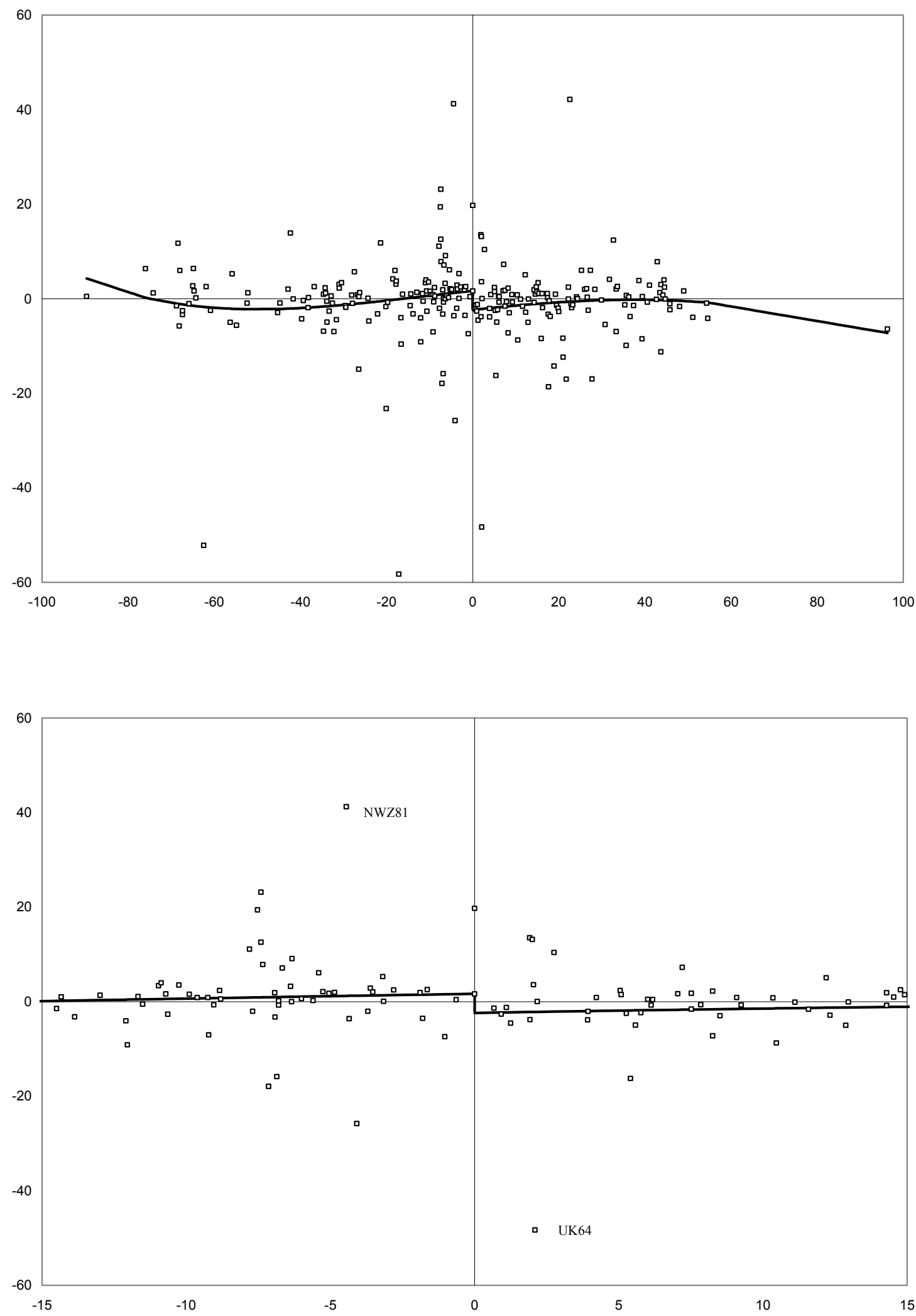


\begin{tabular}{lccccc} 
Table 1. Short-Run RD Estimates of Left-Government Effects (1-Month) \\
\hline Currency Market & $-4.006^{*}$ & $-4.041^{*}$ & $-5.061^{* *}$ & $-6.490^{* *}$ & $-7.341^{* *}$ \\
(Obs. 244) & $(2.254)$ & $(2.259)$ & $(2.425)$ & $(2.535)$ & $(2.885)$ \\
$\quad \mathrm{R}^{2}$ & .016 & .017 & .099 & .249 & .325 \\
Bond Market-Average & 0.098 & 0.125 & .092 & $0.173 *$ & $.182^{*}$ \\
(Obs. 232) & $(0.081)$ & $(.082)$ & $(.089)$ & $.093)$ & $(.107)$ \\
$\mathrm{R}^{2}$ & .019 & .029 & .097 & .281 & .343 \\
Bond Market-Spread & 0.104 & 0.143 & 0.156 & 0.066 & .231 \\
(Obs. 154) & $0.115)$ & $(.128)$ & $(.122)$ & $.168)$ & $(.179)$ \\
$\mathrm{R}^{2}$ & .031 & .034 & .309 & .324 & .546 \\
\hline Polynomial & Third & Fourth & Fourth & Fourth & Fourth \\
Country Dummies & No & No & Yes & No & Yes \\
Year Dummies & No & No & No & Yes & Yes \\
\hline \multicolumn{5}{l}{ Parentheses contain standard errors. **Significant at the $5 \%$ Level; *Significant at the 10\% Level. } \\
\hline \multicolumn{5}{c}{}
\end{tabular}

\begin{tabular}{|c|c|c|c|c|c|}
\hline Currency Market & 5.324 & 4.892 & 2.394 & $12.525^{*}$ & 11.233 \\
\hline (Obs. 244) & $(7.088)$ & (7.069) & (7.399) & $(6.971)$ & $(7.791)$ \\
\hline $\mathrm{R}^{2}$ & .010 & .021 & .146 & .422 & .499 \\
\hline Bond Market_-Average & -.066 & .014 & .043 & -.062 & -.040 \\
\hline (Obs. 232) & $(.388)$ & $(.397)$ & $(.435)$ & $(.421)$ & $(.487)$ \\
\hline $\mathrm{R}^{2}$ & .018 & .022 & .070 & .365 & .415 \\
\hline Bond Market—Spread & -.093 & -.100 & -.207 & .090 & .154 \\
\hline (Obs. 154) & $(.310)$ & $(.348)$ & $(.377)$ & $(.468)$ & $(.544)$ \\
\hline $\mathrm{R}^{2}$ & .010 & .010 & .092 & .274 & .400 \\
\hline Polynomial & Third & Fourth & Fourth & Fourth & Fourth \\
\hline Country Dummies & No & No & Yes & No & Yes \\
\hline Year Dummies & No & No & No & Yes & Yes \\
\hline
\end{tabular}

